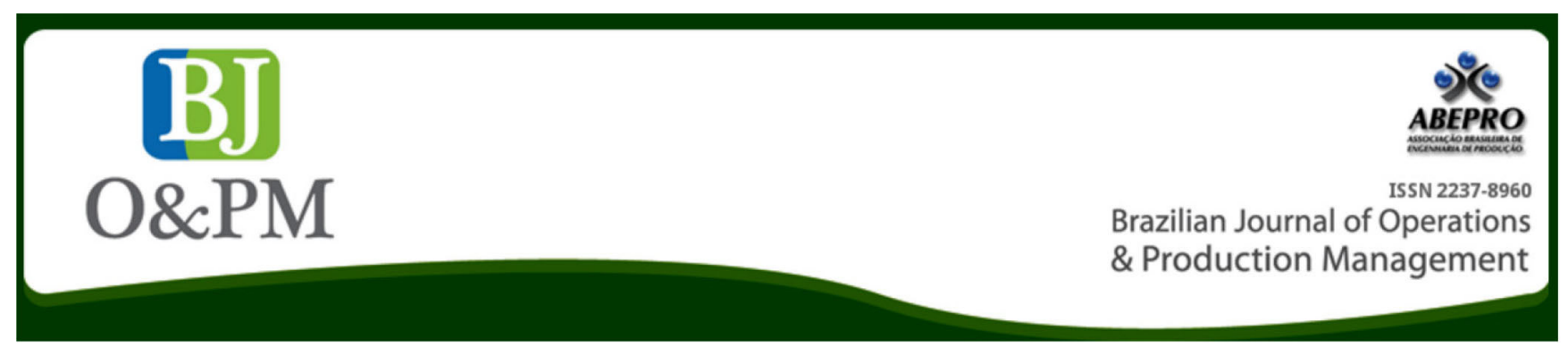

\title{
MULTIMODAL LOGISTIC PLATFORMS STRUCTURE ANALYSIS WORLDWIDE: A COMPARATIVE STUDY BETWEEN BRAZILIAN AND FOREIGN PROJECTS
}

\author{
Bianca Marcelo Mamede ${ }^{1}$, Gyovanna Alves e Silva Oliveira ${ }^{1}$, Ricardo Luiz Machado ${ }^{1}$ \\ 1 Pontifical Catholic University of Goiás
}

\begin{abstract}
Multimodal Logistic Platforms - MLPs - provide integration of different modes of transportation, enabling flexibility in the logistic system and generating competitive advantages. Seeking to point out characteristics that an MLP should have to meet the market's need, this study aimed to a comparative analysis between MLP structures operating in Europe, Asia, and North America and two advanced Brazilian projects. Therefore, we present a comparison based on variables such as the nature of the modal, management system, resided area, and types of cargo handled. The results support that the Brazilian projects are similar to the international MLPs and can reach the same level of competitiveness.
\end{abstract}

Keywords: Multimodal Logistic Platform; Modal integration; Logistics; Cargo transportation. 


\section{INTRODUCTION}

Cargo transportation by more than one type of modal characterizes multimodal transportation (SteadieSeifi et al., 2014), thus a Multimodal Logistic Platform - MLP - is defined as the place where more than one transportation modal meets in an integrated way (Alumur et al., 2012). This meeting point increases the transportation flow efficiency making it more reliable, flexible, and sustainable (SteadieSeifi, et al., 2014).

Research conducted on MLP support that the use of multimodal transportation provides benefits, such as the optimization of the logistic infrastructure, the decrease of in transit time of goods, the reduction of logistic costs, and the simplification of logistic processes (Gutiérrez, et al., 2006; SteadieSeifi, et al., 2014; Alumur et al., 2012; Ballou, 1997).

The benefits presented by the multimodality allow for better delivery deadlines, reducing the costs and increasing flexibility towards uncertainties that may occur during the logistic flow (Harris et al., 2015).

Another factor that allows for the reduction of costs is the consolidation of cargo that has similar destinations and characteristics, allowing the cost to be apportioned by the transporting companies responsible for the shipment. A good understanding of a MLP provides cost reduction, by offering a multimodal structure consisting of ground and air transportation, in addition to Road transportation (Alumur et al., 2012).

The management of a successful platform should be based on public partnership for the formalities and bureaucratic operations; and private initiative, to manage the organizational performance of the unity (Dubke et al., 2004). Establishing connections and partnerships forms an integrated network, increasing the efficiency and effectiveness of services rendered with a steady flow of cargo movement, making the market more attractive for suppliers, distributors, and consumers (Long et Grasman, 2012).

According to Dias (2005) there are three MLP classifications: Port Logistic Activity Zones (maritime terminals), Air Cargo Terminals (specialized in air/land Exchange), and Dry (container) Ports (terminals without waterway access located inland).

Based on the presented context formerly discussed, the aim of this study is to perform a comparative analysis between MLPs considered relevant cases in North America, Europe, and Asia and the more advanced projects in Brazil.

\section{METHODOLOGY}

There are several Brazilian projects and studies for the construction of platforms throughout the country with the intent to improve the logistic infrastructure to make it more competitive. However, until the present moment, there is not a working platform complete that may be adopted as a model for others. Therefore, this study sought international models that could be used as reference for the Brazilian projects.

Initially, through literature review carried out in the Capes Database Portal and the national database of theses and dissertations, the field of knowledge of Brazilian Multimodal Logistic Platform was researched. Twenty-two (22) MLP intentions were obtained in Brazilian soil; however, of these, only two projects are at a more advanced level, and thus have relevant data to this study, which are Campinas-SP and Anápolis-GO (AD Diper, 2008; SEGPLAN, 2013; Dubke, 2006; Carvalho et al., 2010; Bastos et al., 2009; Silva, 2008; Silva, et al., 2013; Braga, 2011).

With respect to the MLPs operating in other countries, Boile et al. (2008) have identified the structures in Europe, Asia and North America. According to these authors international database of MLPs are 16 in Asia, 50 in Europe, and 13 in North America.

In order to reach the aims of this research, a full investigation was carried out in places and official documents relating to the platforms formerly identified by Boile et al. (2008), to characterize each of the identified facilities. Considering the 79 analyzed structures, only those without ports and with the same modals existing in the Brazilian projects were considered for the study and therefore served as a parameter for the purposes of this research.

The selection of international MLPs submitted to the study resulted in twenty European platforms, two Asian, and four North American, which will be presented in the next section.

To identify the structural impact of the platforms, content analysis was performed resulting from the review of the literature of this work. Content analysis is the thorough analysis of the texts developed by experts; the opinion of an expert in terms of the thread has a considerable value (Kitchenham et al., 2009). Analyzing systematically the works of SteadieSeifi, et al. (2014), Alumur et al. (2012), Harris et al. (2015), Long et Grasman, (2012), Carvalho et Carvalho (2010), Boyle et al. (2008), Ballou (1997) and Gutiérrez et al. (2006), we observed by word count, presented by Table 1, the incidence of variables: management model, size, types of loads transported, and modal interconnected services. These characteristics of the PLMs were adopted as comparative parameters between platforms. 
Brazilian Journal of Operations \& Production Management

Volume 14, Número 3, 2017, pp. 288-295

DOI: 10.14488/BJOPM.2017.v14.n3.a2

Table 1. Result of content analysis.

\begin{tabular}{|c|c|c|c|c|c|}
\hline \multirow[t]{2}{*}{ Author } & \multicolumn{5}{|c|}{ Words } \\
\hline & Management & $\begin{array}{l}\text { Area, Size, Dimen- } \\
\text { sion, Extension }\end{array}$ & Cargo & $\begin{array}{l}\text { Services delivery, } \\
\text { Services rendered, } \\
\text { multimodal services }\end{array}$ & Modals, Modes \\
\hline SteadieSeifi et al. & 22 & 0 & 12 & 16 & 8 \\
\hline Alumur et al. & 2 & 0 & 6 & 13 & 5 \\
\hline Harris et al. & 12 & 2 & 2 & 2 & 6 \\
\hline Long et Grasman & 3 & 4 & 0 & 1 & 4 \\
\hline Carvalho et Carvalho & 6 & 12 & 1 & 6 & 3 \\
\hline Boile et al. & 15 & 107 & 20 & 217 & 85 \\
\hline \multirow[t]{2}{*}{ Ballou et al. } & 5 & 2 & 0 & 17 & 0 \\
\hline & $\begin{array}{c}\text { Organization, Man- } \\
\text { agement }\end{array}$ & $\begin{array}{c}\text { Geographical area, } \\
\text { Physical space }\end{array}$ & Goods, Product & Services & $\begin{array}{l}\text { Modes of } \\
\text { transport }\end{array}$ \\
\hline Gutierrez, Lopez et Uraga & 7 & 4 & 10 & 5 & 8 \\
\hline
\end{tabular}

The choice of works to be analyzed by means of content analysis was carried out according to the relevance of the work problem involved and the main works that structure the conceptual basis of this research were considered, resulting in eight works. Because the words have different meanings, depending on the context, the authors decided to count manually the words at the moment of reading the work, because there are times when words are mentioned; however, they do not display the feeling desired by the authors; therefore, they cannot be considered.

\section{International MLPs}

The European transportation infrastructure planning is part of the agenda discussed in the Europe 2020 Strategy, whose main goal is to contribute to the mobility of people and goods, in a continuous and safe manner, collaborating to economic growth and competitiveness (EU Official Journal, No. L348, 12\20\2013). The following structures are considered references of the European MLPs (Gran Europe Group):

- MLP Scandinavian Transport Centre (Freight Village) in Denmark has Road, Air, Rail and Waterway modals, with an area of 1,300,000 $\mathrm{m}^{2}$. The services rendered are transshipment, distribution, storage, consolidation and assistance for general shipment. Its management is public-private;

- MLP GVZ Bremen in Germany has Road, Air, Rail and Waterway modals, with an area of $4,720,000$ $\mathrm{m}^{2}$. The services rendered are distribution, storage, loading and unloading of general shipment with a public-private management;
- MLP GVZ Hamburg in Germany has Road, Air, Rail and Waterway modals, with an area of $560,000 \mathrm{~m}^{2}$. The services rendered are movement, storage, loading and unloading, repackaging, reassembling, and transshipment for shipments in general. Its management is public-private;

- $\quad$ MLP GVZ Kassel in Germany has Road, Air, and Rail modals with an area of $850,000 \mathrm{~m}^{2}$. The services rendered area production, storage, trade, loading and unloading of shipments in general. Its management is public-private;

- MLP GVZ Koblenz in Germany has Road, Air, Rail and Waterway modals, with an area of 2,200,000 $\mathrm{m}^{2}$. The services rendered are movement, consolidation, transshipment, loading and unloading, distribution and storage for shipments in general, refrigerated chambers, and dry bulk. Its management is public-private;

- MLP GVZ Rostock in Germany has Road, Air, Rail and Waterway modals, with an area of 1,510,000 $\mathrm{m}^{2}$. The services rendered are production, storage, trade, unloading and loading of shipments in general. Its management is public-private;

- MLP Rheinhafenge Sellschaft Weil am Rhein in Germany has Road, Air, Rail and Waterway modals, with an area of $260,000 \mathrm{~m}^{2}$. The services rendered are movement, transshipment, consolidation, storage, loading and unloading of shipment in general, refrigerated chambers, and dry and liquid bulks. Its management is public-private;

- MLP BILK Kombiterminal in Hungary has Road, Air, Rail and Waterway modals, with an area of $1,000,000$ 
$\mathrm{m}^{2}$. The services rendered are movement, transshipment, consolidation, assistance, storage and loading of shipments in general, refrigerated chambers, and dry and liquid bulks. Its management is private;

- MLP CIM Interporto di Novara in Italy has Road, Air, and Rail modals with an area of $840,000 \mathrm{~m}^{2}$. The services rendered are storage, assistance, and loading and unloading of shipments in general. Its management is public-private;

- MLP Ce.P.I.M.S.p.A. in Italy has Road, Air, and Rail modals with an area of 2,500,000 $\mathrm{m}^{2}$. The services rendered are reception, storage, consolidation, shipment handling, loading, unloading and classification of goods for all types of shipments. Its management is public-private

- MLP Interporto Quadrante Europa in Italy has Road, Air, and Rail modals with an area of 2,500,000 $\mathrm{m}^{2}$. The services rendered are storage, consolidation, and loading and unloading of shipments in general. Its management is public-private; - MLP Bilkakobo-Aparcabisa in Spain has Road, Air, and Rail modals with an area of 200,000 $\mathrm{m}^{2}$. The services rendered are consolidation, storage, loading and unloading of shipments in general, refrigerated chambers, and dry and liquid bulks. Its management is public-private;

- $\quad$ MLP Centro de Transporte de Coslada in Spain has Road, Air, and Rail modals with an area of 1,079,000 $\mathrm{m}^{2}$. The services rendered are reception, storage, loading, unloading and distribution of shipments in general. Its management is public-private;

- $\quad$ MLP ZAISA in Spain has Road, Air, and Rail modals with an area of $402,000 \mathrm{~m}^{2}$. The services rendered are reception, storage, consolidation, loading, unloading and distribution for shipments in general, and refrigerated chambers. Its management is public-private;

- MLP Centro de Transportes de Madrid in Spain has Road, Air, and Rail modals with an area of 338,500 $\mathrm{m}^{2}$. The services rendered are storage, consolidation, loading, unloading and distribution for shipments in general. Its management is public-private;

- MLP Centro de Transportes de Vitoria in Spain has Road, Air, and Rail modals with an area of 700,000 $\mathrm{m}^{2}$. The services rendered are reception, loading, unloading, express deliveries, permanent display, vehicle Sales, service station and technical inspection for shipments in general, and refrigerated chambers. Its management is public-private;

- $\quad$ MLP Ciudad del Transport de Pamplona in Spain has Road, Air, and Rail modals with an area of 608,000 $\mathrm{m}^{2}$. The services rendered are storage, distribution, consolidation, loading and unloading of shipments in general, and refrigerated chambers.

- MLP Azuqueca Dry Port together with the Intermodal Rail Terminal in Spain has Road, Air, and Rail modals with an area of $960,000 \mathrm{~m}^{2}$. The services rendered are storage, consolidation and distribution of shipments in general, and refrigerated chambers. Its management is public-private;

- $\quad$ MLP Logistics Platform of Zaragoza (PLAZA) in Spain has Road, Air, and Rail modals with an area of $13,117,977 \mathrm{~m}^{2}$. The services rendered are loading, unloading and consolidation of shipments in general, refrigerated chambers, and dry and liquid bulks. Its management is public-private;

- $\quad$ PLM ZAL Barcelona in Spain has Road, Air, Rail and Waterway modals, with an area of $715,584 \mathrm{~m}^{2}$. Its movement is for shipments in general having a public-private management.

Chakraborty (2006), discussing the infrastructure in Asia, highlights the efforts put forth in the connectivity to other continents, by establishing strategic links. The MLPs presented stand out in the Asian continent (Bacovis, 2007; Miller, 2009; Schwarzkopf, 2014; Apex, 2011; Ross, 2013):

- $\quad$ MLP Busan New Port Distripark in South Korea has Road, Air, Rail and Waterway modals with an area of 3,070,000 $\mathrm{m}^{2}$. The services rendered are consolidation, customs clearance, packaging, repackaging, and loading and unloading for all shipments. Its management is public-private;

- MLP Gamcheon Distripark in South Korea has Road, Air, Rail and Waterway modals with services rendered in manufacturing, storage, distribution, loading and unloading for shipments of marine and coast products. Its management is public-private.

The MLP projects in the United States are initiated with studies of logistic systems demands, which later are executed through partnerships between the government and private initiative. The MLPs presented are the ones that stand out (U.S. Department of Transportation, 2015; IL STAFF, 2008; Alliance Global Logistics Hub, 2015):

- MLP Alliance Texas in the USA has Road, Air, and Rail modals with an area of $180,000,000 \mathrm{~m}^{2}$. The services 
rendered are distribution, consolidation, loading, unloading and storage for shipments in general. Its management is private;

- $\quad$ - MLP Pureland in the USA has Road, Air, and Rail modals with an area of $12,140,618 \mathrm{~m}^{2}$. The services rendered are manufacturing, assembly, storage, distribution, loading, unloading, research and development for shipments in general, refrigerated chambers, and dry and liquid bulks. Its management is public-private;

- MLP Rickenbacke in the USA has Road, Air, and Rail modals with an area of 5,260,934 $\mathrm{m}^{2}$. The services rendered are exchange, distribution, and consolidation. Its management is public-private;

- MLP Halifax Gateway Logistics Park in Canada has Road, Air, Rail and Waterway modals with an area of $505,850 \mathrm{~m}^{2}$. The services rendered are receipt, transshipment, loading, unloading, distribution and storage for shipments in general, refrigerated chambers, and dry and liquid bulks. Its management is public-private.

\section{BRAZILIAN MLPS}

The Brazilian logistic systems are quite outdated compared to the international scene. Problems with infrastructure, communication, investments destined to no bottleneck operations, and lack of long-term planning are the main barriers found (Ribeiro et Ferreira, 2002).

The Multimodal Logistic Platform found in Goiás (MLPG) is a project that is still under construction, allocated strategically in the city of Anápolis, in the countrysideof Goiás due to its geographic location and to the transport flow of goods (Deloitte, 2013; Bacovis, 2007). The same reasons justify Campinas's MLP as it is the countryside of São Paulo. As to the variables studied, the Brazilian projects are characterized as such:

- MLP Multimodal Logistic Platform of Goiás in Anápolis has Road, Air, and Rail modals with an area of $6,967,790 \mathrm{~m}^{2}$. The services rendered are consolidation, loading, unloading, and storage for shipment in general, refrigerated chambers and dry and liquid bulks. Its management is public-private;

- MLP Multimodal Logistic Platform Viracopos in Campinas has Road, Air, and Rail modals with an area of 7,000,000 $\mathrm{m}^{2}$. The services rendered are consolidation, loading, unloading, and storage of shipment in general, refrigerated chambers, and dry and liquid bulks. Its management is public-private.

\section{Comparative analysis between the foreign and Brazilian MLPs}

The consolidation of the data of the international MLPS presented as a characteristic of functional structure, $100 \%$ the presence of road, rail, and air modal. As to the waterway modal the frequency observed was of $42 \%$. The projects in Campinas - SP and Anápolis - GO have the road, rail, and air modals, and thus, considering these aspects, they are compatible to the international platforms. The absence of the waterway modal does not jeopardize the proper functioning of the platforms because $58 \%$ of them do not present this modal and, according to Boile et al. (2008) classification, they operate in satisfactory levels.

Most of the international MLPs have on average 9 million $\mathrm{m}^{2}$ of useful area to carry out their activities, with the exception of the Asian MPLs which have only 3 million $\mathrm{m}^{2}$. The Brazilian projects have approximately 6 to 7 million $\mathrm{m}^{2}$, which corresponds to approximately $72 \%$ of the parameter reference.

The area destined for Brazilian facilities do not present a strong index of compatibility with the international models. However, this cannot be regarded as something negative, since two Asian platforms are part of the international market with only $33 \%$ of the reference area. Thus, the Brazilian projects need to be well designed and distributed within their possible physical space.

The most common services observed were loading and unloading, consolidation, storage and distribution, all linked to shipments. The MLPs rent their area to several logistic service providers. They are responsible for storage and distribution, and for preparing the shipment for loading and unloading.

The good performance of an MLP is fully connected to the flow of shipment that it is able to move and store, because these points characterize its main demand. This movement of goods is not in real time for all intended destinations, thus the need of warehouses to guarantee the standard conditions for the vessels.

Seeking cost reduction, the logistic service providers agglomerate the shipments that have the same destination making only one trip and dividing the costs between the service providers involved. The consolidation of cargo is fundamental in terms of reducing logistic costs.

Regarding the type of cargo, it was found that $85 \%$ have infrastructure to transport and store in general; $35 \%$ have refrigerated chambers; $27 \%$ have dry bulk; $4 \%$ have liquid bulk and; $4 \%$ have the capacity for all cargo type mentioned. 
The Agência Nacional de Transportes Aquaviários (ANTAQ - National Waterway Transport Agency) defines general cargo as any kind of cargo that may be packaged in boxes, bags, barrels and crates. Shipments of the dry bulk type are dry shipments that are deposited directly in the containers that will be transported. The same definition applies to liquid bulk; however, these shipments are not dry. Refrigerated cargo corresponds to shipments that need mild and constant temperatures throughout the transport and storage cycle (ANTAQ, 2009).

The Brazilian projects will have an infrastructure capable of storing and transporting cargo in general, refrigerated and dry bulk compatible with the highest international indices. In addition, according to ANTAQ (2013), the most transported cargo in the Brazilian soil are grains, minerals, and cargo in general packed in containers; thus, the projects in Anápolis and Campinas are also compatible to the domestic market demand.

MLPs' management is run $73 \%$ by public-private partnerships. The document analysis carried out by the research allows the classification of public agency as a facilitating agent, assisting in bureaucratic issues, such as customs, taxes and tax laws. The private agency is normally responsible for the platform's management, controlling their service providers and accounting for the maintenance and development of the platform.

The Brazilian platforms are also structured by the public-private partnership. However, because of the fact that the projects have not yet been concluded the position of the public and private sectors was not observed. The public-private partnership stands out as a way of MLP management; however, this imposes no obligation on a model because there are other platforms in operation with satisfactory levels of performance where only the private sector administrates the platform's operation.

\section{Final considerations}

Besides improving the economic and social development of the region next to its installations, the MLPs bring benefits to businesses in terms of cost reductions and improvement in the flow the cargo transported. Furthermore, it also contributes to the market in a worldwide scale.

The study observed that the Brazilian project is compatible with the Asian, European, and North American when considering the dimension occupied by the platform, the type of management, integrated modals, and types of cargo transported and stored.

New studies should be developed in order to analyze the access of the modals in the Brazilian projects, whether the transport capacity they have is able to meet the demand flow of shipment.

\section{REFERENCES}

AD Diper - Agência de Desenvolvimento Econômico de Pernambuco. (2008) Plataforma Logística Agroindustrial Miguel Arraes de Alencar.

AllianceTexas. Disponível em: <http://www.alliancetexas. com/AllianceGlobal LogisticsHub.aspx>. Acesso em: 23 de junho de 2015.

Alumur, S. A.; Yaman, H.; Kara, B. Y. (2012) Hierarchical multimodal hub location problem with time-definite deliveries. Transportation Research Part v. 48, pp. 1107-1120.

ANTAQ - Agência Nacional de Transportes Aquaviários (2009). Definições de Termos e Conceitos Técnicos Utilizados. Anuário de 2009. Disponível em: <http://www.antaq.gov.br/ portal/anuarios/portuario2009/termos.htm>. Acesso em: 30 de junho de 2015.

ANTAQ - Agência Nacional de Transportes Aquaviários (2013). Hidrovias Brasileiras Indicadores do Transporte de Cargas. Gerência de Desenvolvimento e Regulação da Navegação Interior. Brasília.

APARKABISA. Disponível em: <http://www.aparkabisa. com/index.html>. Acesso em: 25 de junho de 2015.

Apex-Brasil - Agência Brasileira de promoção de exportações e investimentos (2011). Apresentando o comércio da Coreia do Sul 2011. Disponível em: <http://www.apexbrasil. com.br/portal/> Acesso em: 24 de maio 2014.

Bacovis, M. M. C. (2007) Estudo comparativo das plataformas logísticas europeias $x$ brasileiras, como forma de identificar um modelo que atenda às empresas do PIM. II Congresso de Pesquisa e Inovação da Rede Norte Nordeste De Educação Tecnológica, João Pessoa - PB.

Ballou, R. H. (1997) Department of Operations Research and Operations Management Weatherhead. School of Management Case Western Reserve University Cleveland. Ohio - U.S.A.

Bastos, S. Q. A.; Perobelli, F. S.; Maciel, M. T.; Santos, T. A. S. (2009) Plataforma Logística: estudo da viabilidade de implantação em Juiz de Fora (MG) via caracterização das mercadorias transportadas entre Minas Gerais e Rio de Janeiro. Revista de Economia, Vol. 35, No. 1, pp. 53-73

Boile, M.; Theofanis, S.; Wiede, A. S. (2008) Feasibility of Freight Villages in the NYMTC Region. Task 3 - Description of How a Typical Freight Village Works. Center for Advanced Infrastructure and Transportation Freight and Maritime Program Rutgers, The State University of New Jersey. 
Brazilian Journal of Operations \& Production Management

Volume 14, Número 3, 2017, pp. 288-295

DOI: 10.14488/BJOPM.2017.v14.n3.a2
BPA - Busan Port Authority. <www.busanpa.com/Service. do?id=engmain> Acesso em: 28 de abr. 2015.

Braga, V. (2011) Tipologia e topologia dos projetos de plataformas logísticas multimodais no território brasileiro. Departamento de Geografia - UNICAMP CONPUESP.

Busanpa. Disponível em: <http://busanpa.com>. Acesso em 22 de junho de 2015.

Carvalho, C. C.; Carvalho, M. F. H.; Lima Junior, O. F. (2010) Efficient Logistic Platform Design: The Case of Campinas Platform Icieom. XXX Encontro Nacional de Engenharia de Produção - ENEGEP, São Carlos - SP.

Centro de Transporte de Coslada. Disponível em: <www. ctc-coslada.com>. Acesso em: 25 de junho de 2015.

Centro de Transportes de Madrid. Disponível em: <http:// ctm.es/294-home.html>. Acesso em: 25 de junho de 2015.

Centro de Transportes de Vitoria. Disponível em: <http:// www.ctvitoria.com/ctv1.php>. Acesso em: 25 de junho de 2015.

CePIM S.p.A. Disponível em: <http://www.cepimspa.it/>. Acesso em: 24 de junho de 2015.

Chakraborty, A. B. (2006) Promover Conectividade Física no olhar Político do Oriente da Índia. Jornal de Desenvolvimento de Infraestrutura. Disponível em: <http://joi.sagepub. com/content/1/1/45> Acesso em: 24 abr.2014.

CIM Interporto di Novara. Disponível em: <http://www. eurogateway.it/index.php>. Acesso em: 24 de junho de 2015.

DELOITTE. (2013) Projeto básico do complexo da Plataforma Logística Multimodal de Goiás no município de Anápolis, SEGPLAN.

Dias, J. C. Q. (2005) Logística Global e Macrologística. 10. Edição. Lisboa: Edições Sílabo.

Dubke, A. F. (2006) Modelo de localização de terminais especializados: um estudo de caso em corredores de exportação da soja. Tese submetida ao programa de doutorado em Engenharia Industrial da Pontifícia Universidade Católica do Rio de Janeiro - RJ.

Dubke, A. F.; Ferreira, F. R. M; Pizzolato, N. D. (2004) Plataformas Logísticas: características e tendências para o Brasil. XXIV Encontro Nacional De Engenharia De Produção. Florianópolis - SC.

GRAN EUROPE GRUP. Disponível em: <http://www.graneuropa.es/index.php>. Acesso em: 25 de junho de 2015.

Gutiérrez, J. C. E.; López, P. R. A.; Uraga, P. D. B. (2006) Nuevas estratégias para la competitividad en la gestión de las cadenas intermodales de transporte entre España y Europa. Ekonomiaz: Revista vasca de economia, No. 63, pp. 237-271.

GVZ Bremen. Disponível em: <http://www.gvz-bremen. de/>. Acesso em: 22 de junho de 2015.
GVZ Hamburg. Disponível em: <http://www.gvz-altenwerder.de/195.0.html>. Acesso em: 22 de junho de 2015.

GVZ Kassel. Disponível em: <www.zrk-kassel.de/gvestart. htm>. Acesso em: 23 de junho de 2015.

GVZ Koblenz. Disponível em: <http://www.koblenz.de>. Acesso em: 23 de junho de 2015.

GVZ Rostock. Disponível em: <http://www.koe-rostock.de/ projekte-gvz.php>. Acesso em 23 de junho de 2015.

Halifax Gateway Logistics Park. Disponível em: <http:// www.halifaxgateway.com/en/home/default.aspx>. Acesso em: 30 de junho de 2015.

Harris, I.; Wang, Y; Wang, H. (2015) ICT in multimodal transport and technological trends: Unleashing potential for the future. International Journal Production Economics, Vol. 159, pp. 88-103.

IL Staff Report. Memphis: North America's Logistics Center. Disponível em: <http://www.inboundlogistics.com/cms/ article/memphis-north-americas-logistics-center/> publicado em: 10-2008. Acesso em: 17 de agosto 2014.

Interporto Quadrante Europa. Disponível em: <http:// www.quadranteeuropa.it/>. Acesso em: 24 de junho de 2015.

Kitchenham, B. et al. (2009) Systematic literature reviews in software engineering - A systematic literature review. Information and Software Technology, Vol. 51, pp. 7-15.

Long, S.; Grasman, S. E. (2012) A strategic decision model for evaluating inland freight hub locations. Research in Transportation Business \& Management, Vol. 5, pp. 92-98.

Millar, M. (2011) Hong Kong - Leading Global Logistics Hub. Disponível em: http://www.3plwire.com/2011/08/15/ hong-kong-leading-global-logistics-hub/

Plaza Logística. Disponível em: <www.plazalogistica.com>. Acesso em: 25 de junho de 2015.

Pureland. Disponível em: <http://www.purelandindustrialcomplex.com/map.htm>. Acesso em: 25 de junho de 2015.

Rail Cargo Terminal. Disponível em: <http://www.bilkkombi.hu/index.php?id=97>. Acesso em: 24 de junho de 2015.

Regulation (EU) No. 1315/2013 of the European Parlament and of the Council of 11 December 2013. Official Journal of the European Union, L 348/1, 20 de Dec. 2013.

Rheinhafenge-Sellschaft Weil Am Rhein. Disponível em: $<$ http://www.rheinhafen-weil.de>. Acesso em 23 de junho de 2015.

Ribeiro, P. C. C.; Ferreira, K. A. (2002) Logística e transportes: uma discussão sobre os modais de transporte e o panorama brasileiro. In: XXII Encontro Nacional de Engenharia de Produção, Curitiba - PR. 
Rickenbacker Global Logistics Park. Disponível em: <http://www.rickenbackerglp.com/main.aspx>. Acesso em: 30 de junho de 2015.

Ross, S. Logistics - an underdeveloped sector. Jornal JLL China 50 Logistics, 2013. Disponível em: <http://www.joneslanglasalle.com/China50/en-gb/Pages/China50-Logistics-Warehousing-Industrial.aspx> Acesso em: 11 de maio de 2014.

Scandinavian Transport Centre. Disponível em: $<w w w . k o e-$ gehavn.dk>. Acesso em: 22 de junho de 2015.

Schwarzkopf, H. Hong Kong como um centro de logística na Ásia (tradução da pesquisadora). Disponível em: <http:// www.warehousinglogisticsinternational.com/news-details/ hong-kong-leading-global-logistics-hub-1/> Acesso em: 17 de maio de 2014.

SEGPLAN. (2013) Secretaria de Estado Gestão e Planejamento do Estado de Goiás. Plataforma Logística Multimodal de Goiás. Audiência Pública.

Silva, O. C. T. (2008) Um procedimento para a concepção de um modelo de plataforma logística regional: características e tendências para o desenvolvimento sustentável da Região Amazônica. XVII COPPE da Universidade Federal do Rio de Janeiro.

Silva, R. M.; Senna, E. T. P.; Lima Jr., O. F. Utilização da parceria público-privada em projetos de plataforma logística no brasil. XVI Simpósio de Administração da Produção, Logística e Operações Internacionais. 2013.

Steadieseifi, M.; Dellaert, N.; Nuijten, W.; Van Woensel, T. (2014) Multimodal freight transportation planning: A literature review. European Journal of Operational Research, Vol. 233, pp. 1-15.

U.S. Department of Transportation. Federal Railroad Administration. Disponível em: <https://www.fra.dot.gov/Page/ P0001>. Acesso em: 23 de junho de 2015.

ZAISA. Disponível em: <http://www.zaisa.com/portada/ portada.php>. Acesso em 25 de junho de 2015.

ZAL. Disponível em: <www.zal.es>. Acesso em: 25 de junho de 2015. 